$9-1-2013$

\title{
Oil Prices Once Again: The Link Towards Middle East Economies
}

\author{
Erhan Aslanoğlu \\ Marmara University \\ Pinar Deniz \\ Marmara University
}

Follow this and additional works at: https://ecommons.luc.edu/meea

Part of the Economics Commons

\section{Recommended Citation}

Aslanoğlu, Erhan and Deniz, Pinar, "Oil Prices Once Again: The Link Towards Middle East Economies". Topics in Middle Eastern and North African Economies, electronic journal, 15, Middle East Economic Association and Loyola University Chicago, 2013, http://www.luc.edu/orgs/meea/

This Article is brought to you for free and open access by the Journals and Magazines at Loyola eCommons. It has been accepted for inclusion in Topics in Middle Eastern and North African Economies by an authorized administrator of Loyola eCommons. For more information, please contact ecommons@luc.edu. cc) (i) (2)

This work is licensed under a Creative Commons Attribution-Noncommercial-No Derivative Works 3.0 License. (C) 2013 the authors 


\title{
OIL PRICES ONCE AGAIN: THE LINK TOWARDS MIDDLE EAST ECONOMIES
}

\author{
Erhan Aslanoğlu* \\ Pinar Deniz ${ }^{\dagger}$
}

\begin{abstract}
Recently, it is observed that current account surplus in oil exporting countries have been rising with the help of peaking oil prices. Expansionary monetary policies of major central banks boosting the speculation on commodity prices, political turmoil in Middle East region which is called the "Arab Spring," and most importantly rising energy demand in the world economy due to high average growth rates of developing countries are argued to be the main reasons for the rising oil prices. This study aims to clarify the global stance of oil prices examining causes and how this affects Middle East economies (MEEs) separately from the rest of the world. The focus of the study will be on the demand pull factors for the rise in oil prices. As for causes, Chinese and Indian economic growth levels are examined since the oil demand of these countries constitutes a crucial ratio of the world oil demand. As for effects, the rise in oil price brings about a trade surplus which contributes to the growth of MEEs. Shortly, this study investigates whether there is a transmission mechanism from South and East Asia to MEEs via oil prices. For the time series analysis, Pesaran et al. (2001) bounds testing are used. Empirical findings confirm the link towards MEEs.
\end{abstract}

Keywords: Oil prices, Capital flows, Economic Growth, Bounds Test JEL classification: O4O, F32, C22, C23

\footnotetext{
* Marmara University, Turkey, Faculty of Economics and Administrative Sciences, Economics Department, email: easlan@marmara.edu.tr

${ }^{\dagger}$ Marmara University, Turkey, EU Institute, Research Assistant; Marmara University, Economics Department, PhD Student, e-mail: pinar.deniz@marmara.edu.tr
} 


\section{INTRODUCTION}

Many studies show a strong correlation between the oil prices and the growth rates of oil exporting countries (Dasgupta et al., 2002). Oil prices have always played a crucial role in determining the cycles of the world economy. The world economy faced with stagnation and high inflation, which is called stagflation, by the 1970s and early 1980s. The main reason for the stagflation was the dramatic rise in oil prices from $\$ 6$ to $\$ 45$ per barrel with supply restrictions of OPEC cartel. In contrast to that period, oil prices have significantly fallen during 1990s due to oil glut after the breakdown of OPEC cartel. At times when oil prices are high, oil importers suffered a lot due to non-sustainable current account deficits whereas oil exporters benefited a lot with tremendous rise in their current account surpluses. At times when the oil prices are low, oil importers benefited a lot with sustainable current account deficits whereas oil exporters faced with growth problems as a result of falling export revenues.

In the past ten years, oil prices tended to rise again reaching new records highs of history. Oil prices were about $\$ 140$ per barrel just before the global economic crisis in 2008. Thereafter, it has sharply fallen to even $\$ 35$ per barrel in 8 months. However, it has started to rise again by 2010 and exceed $\$ 100$ per barrel in 2012. Although the nominal oil prices tend to move to new highs recently, current prices are still significantly less than its historical records in real terms. As is shown in (Hamilton, 2012), the most expensive oil price was observed in 1859 at the birth of the industry. The price of the oil was $\$ 20$ per barrel in 1859 . It corresponds $\$ 500$ per barrel when the 24 -fold increase in consumer prices are considered. Currently, it is almost one fifth of that price. However, it is almost ten times higher than the price of oil in 1998.

The recent peak in oil prices started to significantly affect the dynamics of the world economy and the politics. This time is different as the causes of the rising oil price are also different. There are many factors which are argued to be the factors behind the rise in oil prices in the last decade. Expansionary monetary policies of major central banks boosting the speculation on commodity prices, political turmoil in Middle East region, which is called the "Arab Spring," and most importantly rising energy demand in the world economy due to high average growth rates of developing countries are argued to be the main reasons for the rising oil prices. Among those factors, rising oil demand can be considered as the fundamental 
source of the rising oil prices. Expansionary monetary policies and the "Arab Spring" are likely to be the temporary and technical factors for the peak in oil prices. Therefore, this study will focus on demand pull factors for the unprecedented move in oil prices. Among the developing countries, China and India have been the top two leading countries of global growth in the last decade. (IMF, WEO, 2012). They have been the engines of the world economy. As a result, these two country should also been the main source of the oil demand in the world economy which in turn are likely to shape the world oil prices. One of the aims of this study is to show whether the China and India have really caused the high oil prices.

On the other hand, this high oil prices have contributed a lot to the export earnings and current account surpluses of oil exporting countries. For example, some (MEEs) had CAS (current account surplus) to GDP ratio exceeding 30 percent recently. The second aim of this study is to show whether the high oil prices contributed to the growth rates of MEEs. If it has, one can talk about a transmission mechanism from the growth of China and India to the growth of (MEEs) at this age of globalization. We call this transmission as oil-growth multiplier. The multiplier can also work in the opposite direction. If the growth rates of China and India decelerates, the growth rates of (MEEs) would also slowdown. Indeed, the oil-growth multiplier can further be extended to non-oil producing countries of the middle-east region including Turkey. Strong growth performance of (MEEs) could create a demand for various types of goods and services, especially from the countries located in the region. Rising construction activities of Turkish firms in the region can be given as an example. However, this study will be limited with the likely transmission of Chinese and Indian economic growth on the growth of (MEEs).

High oil prices have contributed positively to the growth rates of (MEEs) in late 1970s whereas the falling prices of the 1990s negatively affected those countries. However, the negative impact of oil prices has stimulated the structural reform efforts of (MEEs) to achieve stability and sustainability of economic growth (Dasgupta et al., 2002). This time the factors behind the high oil prices are different. Whether the high oil prices have disrupted or changed the dynamics of the reform agenda of (MEEs) seems to be an important question to be answered.

Thus, this study aims to clarify the global stance of oil prices, examining causes and how this affects Middle East economies (MEEs) separately from the rest of the world. The focus of the 
study will be on the demand pull factors for the rise in oil prices. As for causes, Chinese and Indian economic growth levels are examined since the oil demand of these countries constitutes a crucial ratio of the world oil demand. As for effects, the rise in oil price brings about a trade surplus which contributes to the growth of MEEs. Shortly, this study investigates whether there is a transmission mechanism from South and East Asia to MEEs via oil prices.

The methodology of the study is based on an econometric model. Basically, Pesaran et al. (2001) bounds test will be employed since the technique is designed for using a dataset without controlling for the integrated order and it allows for utilizing a small dataset. Since our dataset is not long enough and taking difference will worsen the sample size, if each variable does not have the same integrated order for cointegration or stationary analysis, bounds test seems to be the best way to analyze the long run relationship between variables in question.

Within this framework, in the second section, there will be a brief analysis of oil prices and the growth rates of China, India and (MEEs). This section will also discuss the transmission from oil prices to growth in (MEEs) and cover a literature survey on this issue. The third section is devoted to the discussion on the methodology of the study. The fourth section will discuss the empirical findings. Finally, there will be an overall assessment of the study in the conclusion part.

\section{2) From Oil Price to Economic Growth; The Oil -Growth Multiplier}

An inspection on historical oil prices, given in Figure 1, reflects continuous fluctuations, including up and downs until the end of 1990s, a very steep rise until the 2008 crisis and an unremitting increase following the crisis. It is frequently stated that political and economic turmoil easily leads to short run fluctuations in oil prices. However, long run trend of oil prices reflects a very high climb which is mainly attributed to the decline in oil extraction and/or the increase in world oil demand. At this point, Hamilton (2008) indicates that there are some economic and natural restrictions on oil supply: storage arbitrage

${ }^{1}$, financial futures contracts ${ }^{2}$, and that oil is a deplorable resource. Also the fact that the 
Organization of the Petroleum Exporting Countries (OPEC) $)^{3}$ is acting as a cartel, and that there is not a high level of cheating by supplying oil at a lower rate, leads to price run-ups when one country is reducing its supply. Moreover, there are some additional supply restrictions by country leaders' own will ${ }^{4}$ under the claim of preserving oil for future generations. Figure 2 shows the total oil supply and consumption from 1980 to 2011. It is observed that except for the end of 1990s and the beginning of 2000s, supply is consistently higher than consumption.

Figure 1: Annual Crude Oil Price (1986-2011)

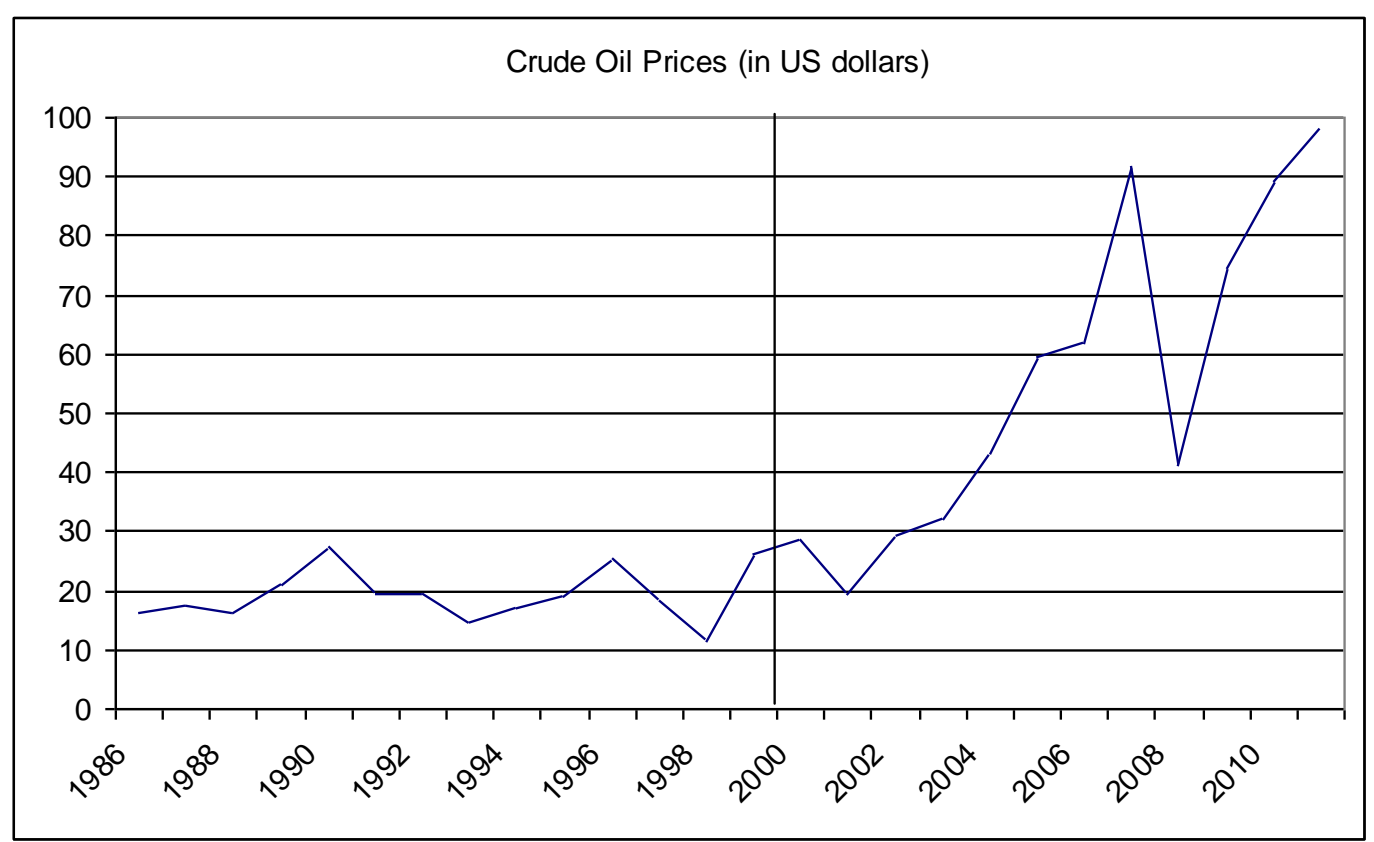

Source: World Oils (http://www.worldoils.com/oilprice.php)

Hamilton (2012), based on the overall social welfare perspective, states that current production should be balanced; otherwise resources will be unavailable to future generations. He claims that oil price is lower than it should be for an exhaustible recourse and a shift in how the price of oil is determined is possible.

\footnotetext{
${ }^{1}$ Storage arbitrage refers to the case that the price you will expect to sell oil gets equal to the costs while you are buying oil. Hamilton (2008) explains that in order to buy oil, you need to borrow money for the oil and for the storage tank. The time you will sell the oil, the oil price should be higher than your borrowing plus interest rate so as to earn some profit. Based on the risk perceptions, there may be some limit on oil supply.

${ }^{2}$ By futures contracts he refers to the possibility that oil prices are expected to be higher and that the suppliers will go storing under the expectation of earning higher profits. This is a potential financial limit on oil supply.

${ }^{3}$ OPEC members are Algeria, Angola, Ecuador, Iran, Iraq, Kuwait, Libya, Nigeria, Qatar, Saudi Arabia, United Arab Emirates, and Venezuela.

${ }^{4}$ Hamilton (2008, p.12).
} 
The trend of oil prices are very crucial since oil is still the dominant energy resource of the world and many economic indicators are shaped by the movements in oil prices. Hamilton (2008) highlights this dependence by indicating that price elasticity of short run demand is low for oil. According to him, real oil prices tend to have three features: (1) it has a permanent trend, (2) forecast is difficult, and (3) its fluctuations are driven by different regimes at different points in time.

Middle East economies are at the center of this study and we will examine whether there exists a transmission mechanism from the impact of world oil demand as one of the main drivers of oil price movements to economic growth in Middle East economies. Hence, the focus of this study is two-folds. The first part scrutinizes world's highest growing countries, China and India, as the causes for oil price fluctuations. Many studies point out that these countries are the crucial responsibility due to their growing oil demand. Together with the liberalization reform in China by 1978 and India by 1991, these two economies have dominated the world in high growth rates, as shown in Figure 3.

Figure 2: Total Petroleum Supply and Consumption (Thousand Barrels Per Day)

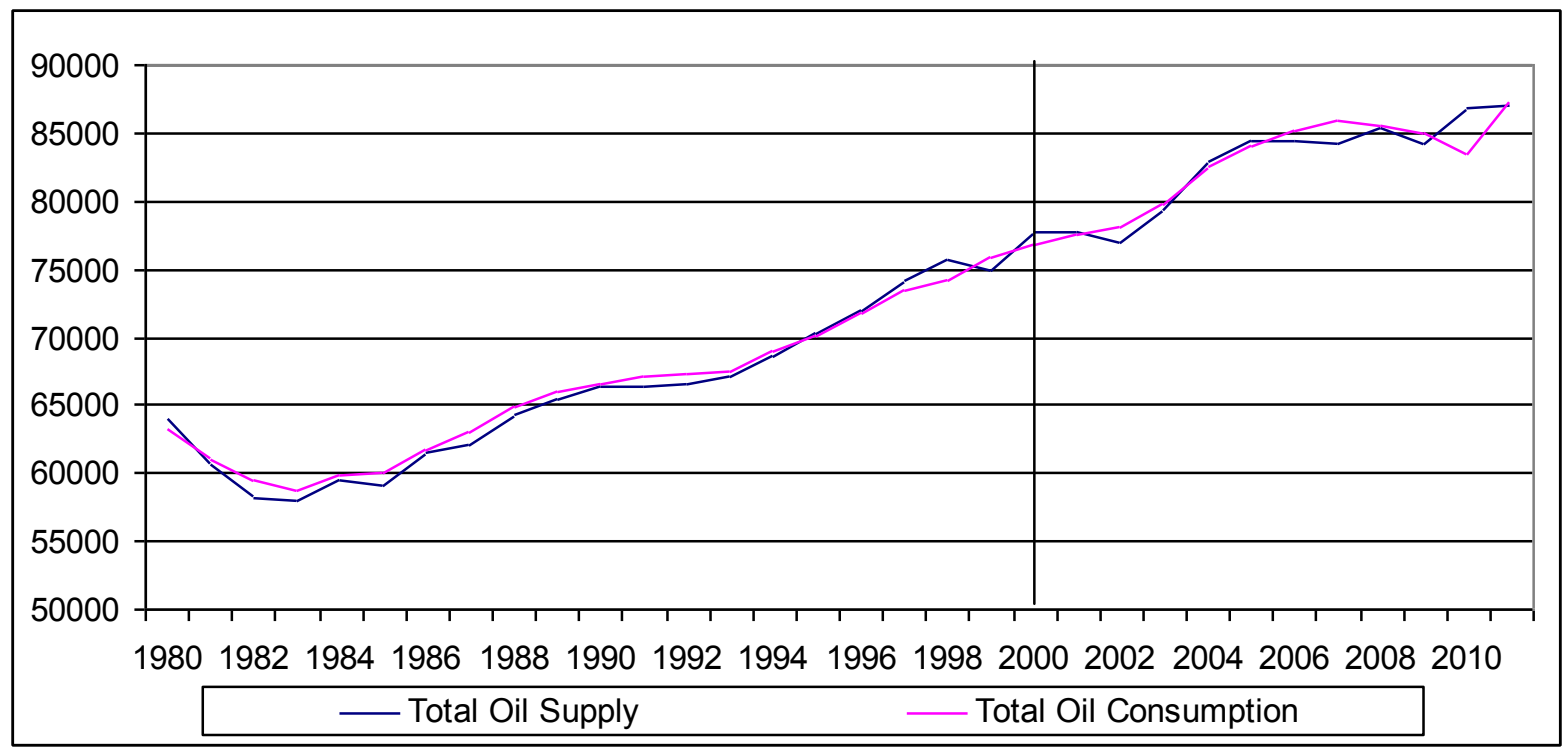

Source: www.eia.gov 
Figure 3: Annual Growth Rate of China and India (per cent) (1986-2011)

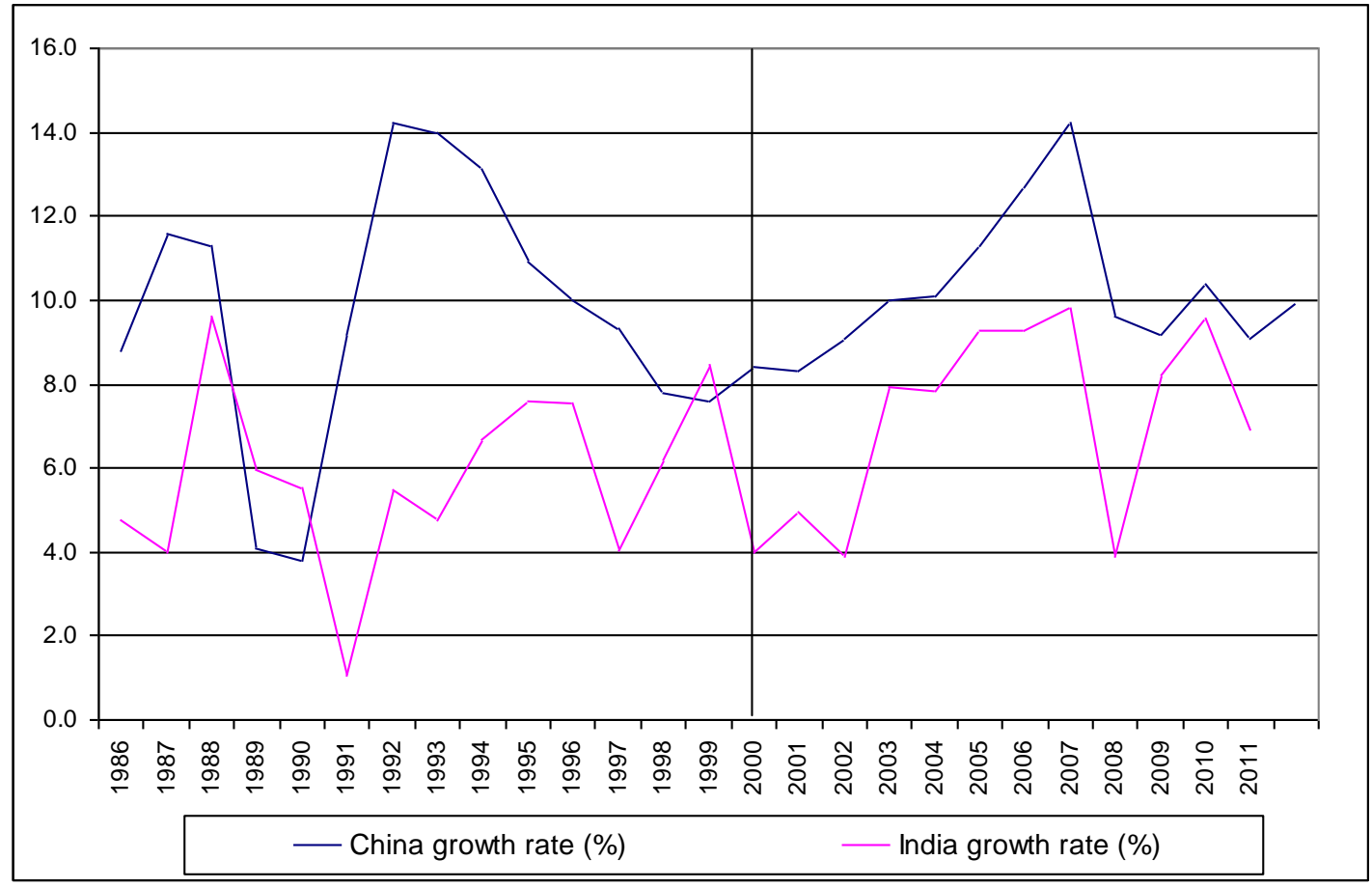

Source: World Bank (www.data.worldbank.org)

Regarding the "causes side" of oil price movements, there are numerous studies many of which include China and India as the main drivers. One of the highly cited studies, Hamilton (2008) inspects the factors leading to changes in crude oil prices. He explains economic, financial, natural and other factors that are responsible for oil price fluctuations. In addition to these factors, he mentions that China and some other economies have growing oil demand and if this rise remains ${ }^{5}$, it will lead to a climb in the oil price. Kilian (2008) stated that the real price of oil has been increasing since 2002. He explains that recurring positive aggregate demand shocks by highly growing countries, such as India and China impels this increase. According to Smith (2009), the biggest shock to the run-up in oil prices by 2000s is driven by the rapid economic growth in China and other developing nations due to their sharp rise in oil demand. Similarly, Leung (2010) indicates that Chinese oil consumption growth has increased remarkably since the 1990 s due to dynamic growth in industry and transport. One of the

\footnotetext{
${ }^{5}$ Hamilton (2008) mentions about a logarithmic trend and makes a projection. According to his projection, by 2020 China would be consuming 20 million barrels per day (mb/d) and by 2030 would be consuming $40 \mathrm{mb} / \mathrm{d}$.
} 
recent studies on the causes side, $\mathrm{Mu}$ and Ye (2011), analyze how China's net oil import affects crude oil price using monthly data from 1997 to 2010. Using VAR analysis, which gives short run results for the variables in question, they observe that response of the real oil price to China's oil demand shocks is statistically insignificant which is contradictory to the dominant view. Ghosh (2009) focuses on Indian economy and observes that there is a causal link from economic growth to crude oil import for over the period 1970-2006 and states that the price elasticity of demand for crude oil is low both in the short and long run for India.

It can be argued that high economic growth of South and East Asian economies leads to oil demand boom by these economies which further leads to a rise in oil prices. The critical point is that OPEC economies do not refrain too much from adapting their supply to world oil demand due to the risk of a deep crisis as experienced in 1970s which has shaken the economies of oil-exporting economies. Since the oil demand of East Asian economies is very significant, it is possible to claim that these economies seem to be one of the essential determinants of oil supply of OPEC. Hence, South and East Asian economies, overtime, may have formed a dependence factor for oil price movements. Upward price movements in oil lead to export revenues in oil exporting countries which contributes to their economic growth. Downward movements lead to diverse effects if there is a high economic dependency on oil industry for these countries, even after economic reforms mentioned before.

Regarding the "effects side" of oil price, Farzanegan and Markwardt (2009) using VAR technique analyses the relationship between oil price shocks and major macroeconomic variables in Iran for the period between 1975-2006. They state that the Iranian economy is very vulnerable to the negative oil price shocks. They obtain a strong positive relationship between positive oil price changes and industrial output growth. Farzanegan and Markwardt (2009, p.146) explain the mechanism as follows: positive oil price shocks lead to a rise in real effective exchange rate and appreciation in domestic currency in mid run, which is one of the syndromes of a Dutch disease. This reduces the price of imports and increases the price of exports. Likewise, Esfahani et al. (2010) using quarterly data over the period 1979-2006 for the Iranian economy and examines the relationship between real output, real money balances, inflation, exchange rate, oil exports, and foreign real output. They state that oil exports contribute to real income through real capital accumulation both in the long run and short run. It is observed that especially after the run-up in oil prices by 2002 , led to a relatively high growth for Iran that has lasted several years. 
Figure 4: Annual Growth Rates of Middle East Countries (\%)

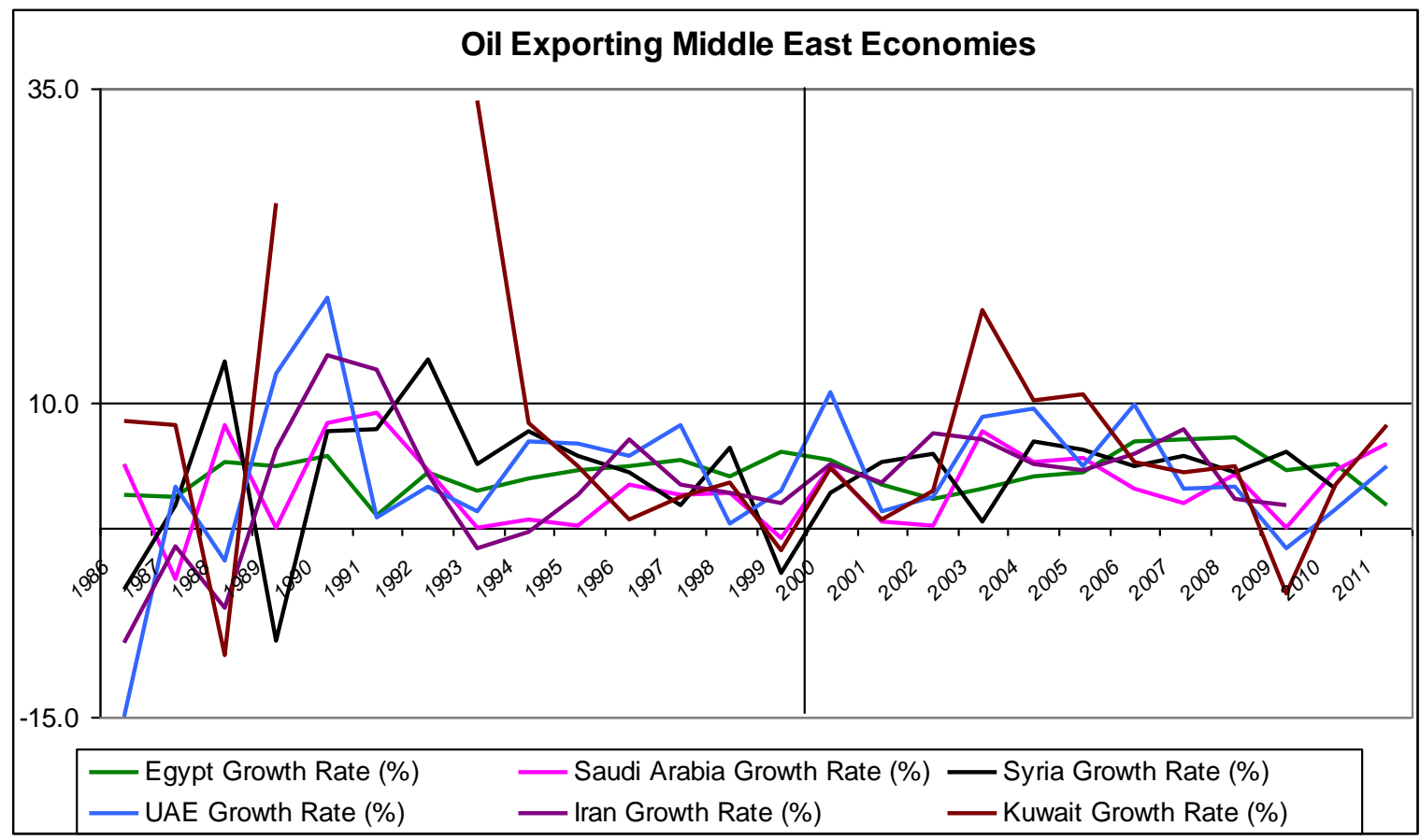

Source: World Bank (www.data.worldbank.org)

\section{3) METHODOLOGY}

\subsection{Bounds Test}

Differently from the most econometric techniques, Pesaran et al. (2001) bounds test allows for using unit root and stationary series at the same time. In other words, the information obtained from the data does not change as taking differences so as to obtain series that are of same integration order is neglected. Bounds test is an ARDL-based cointegration procedure. $\begin{array}{llll}\text { First, conditional } & \text { error } & \text { correction } & \text { (ECM) }\end{array}$ 8 is constructed:

$$
\Delta Y_{t}=c+(t)+\alpha_{1} Y_{t-1}+\alpha_{2} X_{t-1}+\sum_{i=1}^{p} \beta_{i} \Delta Y_{t-i}+\sum_{j=0}^{q} \delta_{j} \Delta X_{t-j}+\varepsilon_{t}
$$

where $Y$ and $X$ refer to endogenous and exogenous variables, respectively; and $c$ is the constant and $t$ is the trend term.

\footnotetext{
${ }^{8}$ The model and the empirical results depend on the lag selection. Accordingly, Pesaran et al. (2001) highlights that the number lags must be high enough to overcome the serial correlation problem, but low enough to prevent over parameterization problem.
} 
Instead of applying unit root tests, Pesaran et al. (2001) give two critical values as lower bound of stationary variable case and upper bound of I (1) series. In order to claim that conditional $\mathrm{ECM}^{9}$ reflects a long run relationship, $\mathrm{F}$ (joint test) and $\mathrm{t}$ (single test) statistics must be over the upper bound critical values. If the calculated statistics are between the two critical values, then the result is inconclusive. First of all, the lagged level coefficients must be jointly significant, i.e.,

$\mathrm{H}_{0}: \alpha_{1}=\alpha_{2}=0$ must be rejected. ${ }^{10}$

Second, the lagged level coefficient of the dependent variable, i.e.,

$\mathrm{H}_{0}: \alpha_{1}=0$ for (1) must be rejected.

After ensuring the existence of a levels relationship, we estimate long run and short run parameters which is the standard ARDL method. First, ARDL (p, q) is modeled as;

$$
Y_{t}=\mathrm{c}+t+\sum_{i=1}^{p} \lambda_{i} Y_{t-i}+\sum_{j=0}^{q} \eta_{j} X_{t-j}+\varepsilon_{t}
$$

After specifying the lag order of the ARDL model via information criteria, the long run coefficients are obtained. Finally, in the short dynamics model, the first lag of the equilibrium error is included instead of the lagged values of the level coefficients as:

$$
\Delta Y_{t}=\mathrm{c}+\sum_{i=1}^{p-1} \lambda_{i} \Delta Y_{t-i}+\sum_{j=0}^{q-1} \eta_{j} \Delta X_{t-j}-\pi \hat{e}_{t-1}+\varepsilon_{t}
$$

where $\pi$ is the error correction coefficient and shows how quickly the model comes back to equilibrium.

\footnotetext{
${ }^{9}$ When the conditional ECM is constructed, the residuals must be checked for serial correlation. Hence, we use Breusch-Godfrey Serial Correlation LM test which has the null of no serial correlation. For the lag selection, AIC or SIC can be used to choose the best model. We employed the SIC for the lag selection.

${ }^{10}$ The critical F statistics for the joint case and the critical t statistics for the single case are given in Pesaran et al. (2001).
} 


\subsection{Data and the Model}

In our model, China and India are selected as the main sources of world oil demand. On the other hand, Saudi Arabia, Iran, United Arab Emirates (UAE), Kuwait, Syria and Egypt are employed as Middle East Economies (MEEs). Dasgupta et al. (2002) split Middle East and North African countries (MENA) into 3 typologies considering their dependence on oil industry. The first group is the core set of OPEC countries that are highly dominated by oil prices, i.e., Bahrain, Kuwait, Oman, Qatar, Saudi Arabia, and UAE. The second group of economies are also affected by this sector but have diversified their economies from the oil industry which are indicated as Iran, Algeria, Syria, Iraq. The last group of countries have diversified economies but are insignificantly and/or indirectly affected from oil industry which are given as Egypt, Morocco, Jordan, Yemen, and Lebanon. Within this framework, our model covers countries from all three typologies of (MENA) countries suggested by Dasgupta et al. (2002).

Annual growth rate and GDP ${ }^{11}$ data for all countries are obtained from World Bank - World Development Indicators (WDI). A long dataset is accessible for many countries but the selected period begins by the date oil price data is available. Hence, the paper covers data between 1986 and 2011, except for India since the economic reform gets started by 1991. Monthly crude oil prices are obtained from World Oils website ${ }^{12}$ and end of the year values are used while transforming to annual dataset.

In reduced form, our analysis suggests a link from Asian economic growth to Middle East economic growth. However, for a more clear investigation we incorporate the component that is responsible of this link, namely as oil price. Therefore, we open our model as given below, where $\pi^{\text {oil }}$ denotes oil price, $y^{A s i a}$ and $y^{M E E}$ denote either growth rate or GDP in logarithmic form for a selected Asian and Middle East country, respectively.

Causes side: $\log \pi^{\text {oil }}=\mathrm{f}\left(y^{\text {Asia }}\right)$

Effects side: $y^{M E E}=\mathrm{g}\left(\log \pi^{\mathrm{oil}}\right)$

\footnotetext{
${ }^{11}$ GDP data are constant GDP levels with local currency.

${ }^{12} \mathrm{http} / / /$ www.worldoils.com/oilprice.php
} 


\section{4) EMPIRICAL FINDINGS}

\subsection{Causes}

For the determination of the impact of countries with highest growth rates, i.e., China and India, on world oil price levels, both GDP growth rates and GDP levels are employed. Long run results via Bounds test technique given in Table 1 shows that Chinese and Indian economies have a positive and significant impact on world oil prices since the largest part of world oil demand is received from these economies.

Table 1: Impact of China and India on Oil Price Dependent variable: Log (Oil Price)

\begin{tabular}{|c|c|c|c|c|}
\hline Countries & \multicolumn{2}{|c|}{ China } & \multicolumn{2}{|c|}{ India } \\
\hline Variable & Growth $^{\mathrm{b}}$ & $\log (G D P)^{b}$ & Growth $^{b}$ & $\log (G D P)^{a}$ \\
\hline Coefficient & $\begin{array}{c}0.105 \\
(0.047)\end{array}$ & $\begin{array}{c}0.808 \\
(0.000)\end{array}$ & $\begin{array}{c}0.136 \\
(0.007)\end{array}$ & $\begin{array}{c}1.011 \\
(0.001)\end{array}$ \\
\hline ECT & $\begin{array}{l}-0.939 \\
(0.000)\end{array}$ & $\begin{array}{c}-0.512 \\
(0.011)\end{array}$ & $\begin{array}{l}-0.534 \\
(0.001)\end{array}$ & $\begin{array}{l}-0.507 \\
(0.008)\end{array}$ \\
\hline Bounds F test & $11.431 * *$ & $15.939 * *$ & $8.251 * *$ & $6.707 * *$ \\
\hline Bounds t test & $-4.530 * *$ & $-4.679 * *$ & $-3.762 *$ & $-3.649 * *$ \\
\hline
\end{tabular}

ECT refers to error correction term for short run adjustment for long run equilibrium. Values above refer to coefficients and values in parenthesis refer to p-values. Critical values for Bounds test with 5\% significance level are 5.73 for Case 3 (unrestricted intercept and no trend) and 7.30 for Case 5 (unrestricted intercept and unrestricted trend) for $\mathrm{F}$ test; -3.22 for Case 3 and -3.69 for Case 5 for $\mathrm{t}$ test. Critical values with $10 \%$ significance level are 4.78 for Case 3 (unrestricted intercept and no trend) and 6.26 for Case 5 (unrestricted intercept and unrestricted trend) for F test; -2.91 for Case 3 and -3.40 for Case 5 for $t$ test. Subscript (a) denotes Case 3, (b) denotes Case 5. (*) and (**) denotes significance at 10\% and 5\%, respectively. Schwarz Information Criteria (SIC) is used for case selection and automatic lag selection.

Average of net oil import of China between 1986-2011 is 1491 thousand barrels per day whereas it is 1208 for India. The average between 1991-2011 is 1962 for China and 1399 for India. Average oil import of these two countries is very close to each other. Considering the recent years, these two country accounts almost ten percent of the world oil demand. Average growth rate between 1986-2011 is 9.9 for China and 6.4 for India, whereas average rate between 1991-2011 is 10.4 for China and 6.5 for India. These numbers suggest that on average regarding these periods, Chinese oil import per GDP growth rate is lower than India. This situation is detected in econometric analysis. Looking at the coefficients in Table 1, it is observed that growth in India reflects a slightly more impact on oil price compared to China. 
However, this condition seems to be changing on behalf of China. Figure 5 reflects that Chinese oil import is rising at a steeper trend compared to India.

Figure 5: Net Oil Imports of China and India (1986-2011) (Thousand Barrels Per Day)

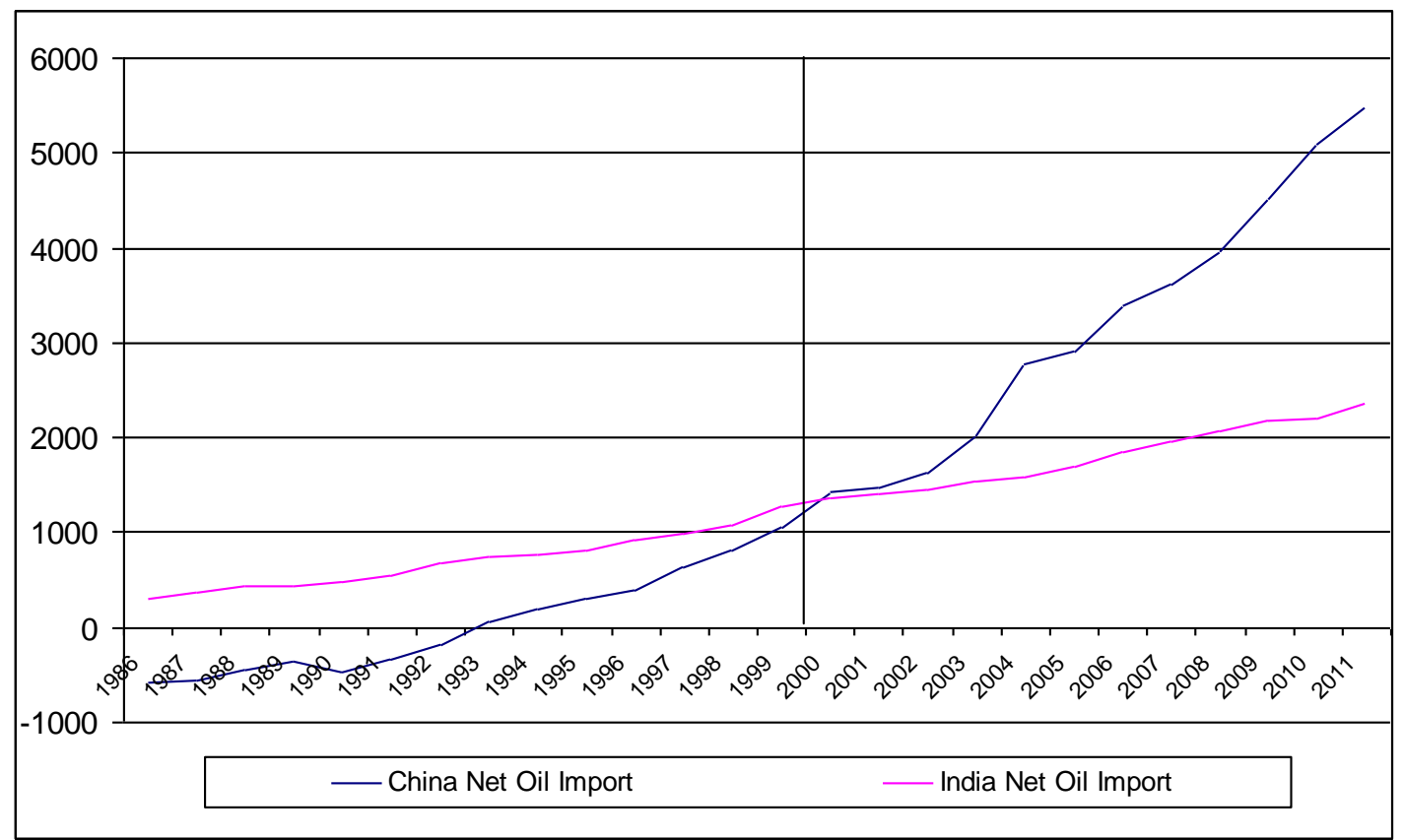

Source: International Energy Statistics (www.eia.gov)

Note: Net Oil Import data are authors' own calculation through subtracting total oil supply from total oil consumption.

\subsection{Effects}

Table 2 highlights the impact of oil prices on the economies of Middle East countries. It is shown that there is a long run relationship between oil prices and GDP levels for MEEs. Saudi Arabia, UAE, Iran and Kuwait reflect significant and positive coefficients as expected since these economies are in the top five lists of net oil exporters by 2011. Via current account balance channel, oil price reveals changes in GDP levels. Long run coefficient for Syria is insignificant and Egypt reflects a very low impact compared to other four MEEs. As shown in Figure 6, net oil production path of Syria and Egypt are apart from the other MEEs. This may be the reason why these countries reflect insignificant or very low coefficients. 
Table 2: Impact of Oil Price on Middle East Economies

Dependent variable: Log (GDP)

\begin{tabular}{|c|c|c|c|c|c|c|}
\hline Countries & $\begin{array}{c}\text { Saudi } \\
\text { Arabia }^{\mathrm{a}}\end{array}$ & $\operatorname{Iran}^{\mathrm{b}}$ & $\mathrm{UAE}^{\mathrm{a}}$ & Kuwait $^{\mathrm{a}}$ & Syria $^{\mathrm{a}}$ & Egypt $^{b}$ \\
\hline Coefficient & $\begin{array}{c}0.480 \\
(0.000)\end{array}$ & $\begin{array}{c}0.107 \\
(0.000)\end{array}$ & $\begin{array}{c}0.532 \\
(0.012)\end{array}$ & $\begin{array}{c}0.470 \\
(0.000)\end{array}$ & $\begin{array}{c}0.280 \\
(0.708)\end{array}$ & $\begin{array}{c}0.033 \\
(0.005)\end{array}$ \\
\hline ECT & $\begin{array}{l}-0.108 \\
(0.011)\end{array}$ & $\begin{array}{c}-0.577 \\
(0.000)\end{array}$ & $\begin{array}{l}-0.458 \\
(0.018)\end{array}$ & $\begin{array}{c}-0.352 \\
(0.005)\end{array}$ & $\begin{array}{l}-0.113 \\
(0.002)\end{array}$ & $\begin{array}{l}-0.799 \\
(0.000)\end{array}$ \\
\hline Bounds F test & $5.547 *$ & $13.866 * *$ & $7.002 * *$ & 4.676 & $6.974 * *$ & $11.998 * *$ \\
\hline Bounds $t$ test & $-3.330 * *$ & $-5.166^{* *}$ & -2.181 & $-3.031 *$ & $-3.533 * *$ & $-4.890 * *$ \\
\hline
\end{tabular}

Same notes as in Table 1.

Figure 6: Net Oil Production of Middle East Economies

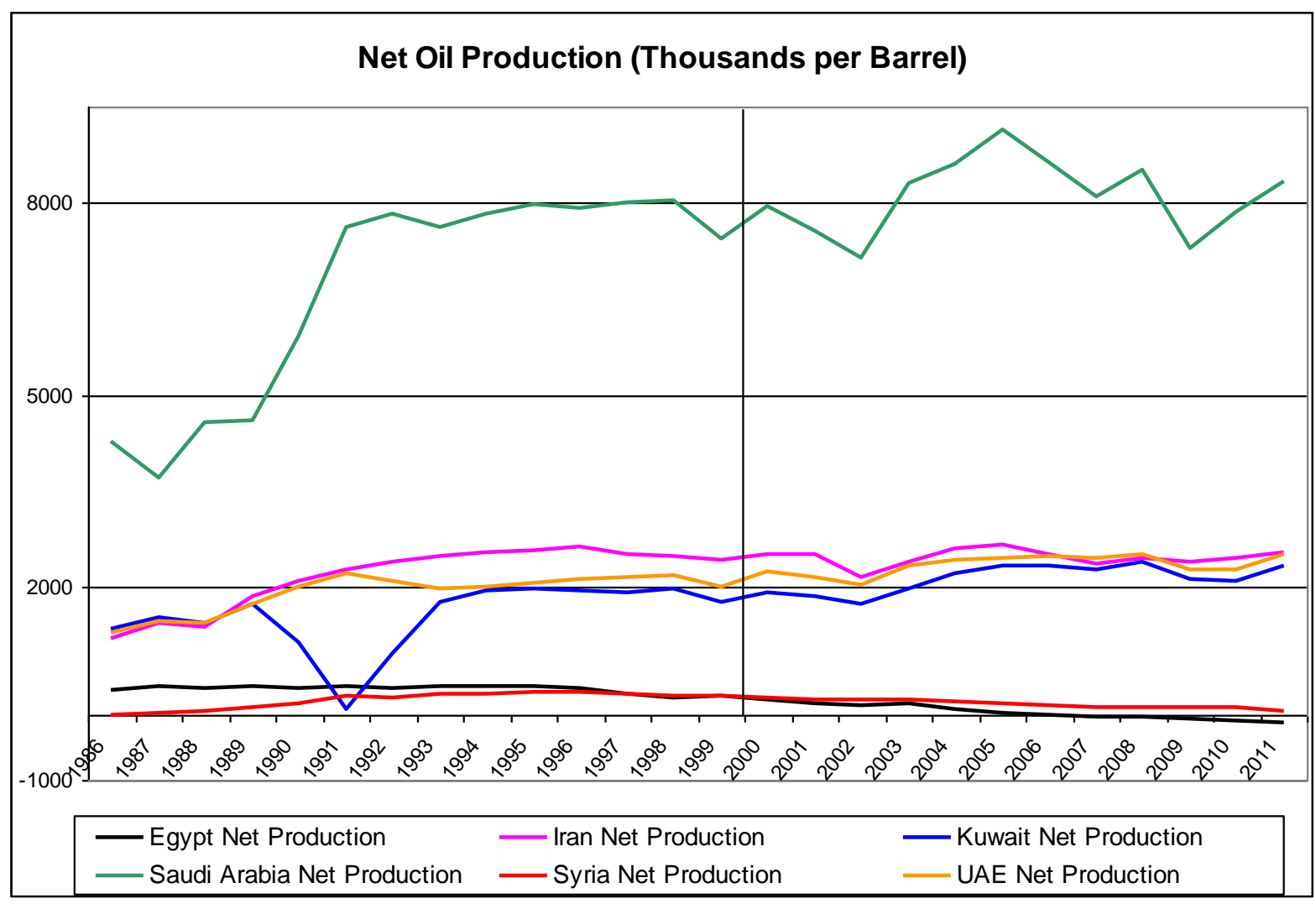

Source: International Energy Statistics (www.eia.gov)

Note: Net Production data are authors' own calculation through subtracting total oil consumption from total oil supply.

Referring to the classification of Dasgupta et al. (2002), such a distinction is consistent with our findings since economies with significant and high coefficients only belong to the first 
group of Dasgupta et al. (2002) classification. Economic and political dynamics of Egypt and Syria could be assessed apart from the first group of Middle East countries.

\section{5) Conclusion}

This study analyzes the transmission of growth from China and India to Middle East economies. Long run relationship analyses via Pesaran et al. (2001) bounds test technique reveals that there is both a positive link from Chinese and Indian growth rate to oil prices, and from oil prices to growth rates of Middle East economies. Empirical findings verify the dependence of economic growth of MEEs on growth rates of highest growing countries through their oil demand boom. However, MEEs whose economies are not dominated by oil industry are detached from this link since their coefficients are either insignificant or low compared to MEEs that are dominated by oil industry.

As is argued in Dasgupta et al. (2002), falling oil prices led (MEEs) to economic reforms to cope with the growth problems. (MEEs) have seemed to be benefiting from the high oil prices in the past ten years. It is an important question now whether (MEEs) have stopped to economic reform process or not with the rising oil prices. An oil-growth multiplier seems to be working in favor of the (MEEs). In order to have a sustained and stable growth, those (MEEs) need to have growth dynamics independent from the oil prices. It is because of the fact that oil prices may not go up forever and/or it will eventually come to a halt leaving those MEEs more vulnerable in the future.

Among the countries analyzed in this study, Kuwait's oil industry accounts for $80 \%$ of government revenue. Petroleum and petrochemicals account for nearly half of GDP and 95\% of export revenues. It is a highly oil dominated country. Other major industries include shipping, construction, cement, water construction materials and financial services. Kuwait has a well developed banking system. On the other hand, Non-oil growth in Kuwait is highly dependent on government expenditures. About 80 percent of the Kuwaiti labor force is employed in the public sector. Kuwait has achieved budget and trade surpluses for thirteen years in a row. Nevertheless, it seems to have done little regarding the quality of its infrastructure, health, education and on business environment indicators to substitute non-oil sectors to growth dynamics (IMF, Kuwait-2012 Article IV Consultation Concluding Statement of the IMF Mission) 
Saudi Arabia which is one of the biggest countries of the Middle East region has also an economy dominated by oil. According to recent figures, oil accounts for more than $95 \%$ of exports and $70 \%$ of government revenue and $45 \%$ of GDP in Saudi Arabia. This economy also depends on government expenditures to a great extent. The manufacturing industry accounts for $10 \%$ of the total GDP where half of the value added in manufacturing is created in petrochemicals industries. Services constitutes about the 30 percent of the GDP. Most of the services are in construction, finance and insurance. If global consumption continues to grow at its current trend, the oil reserves of Saudi Arabia are likely to expire within 50-60 years. Therefore, as in many (MEEs), economic diversification seems to be essential. Saudi Arabia has implemented eight development plans until 2010. It is observed that those plans have been delayed or not fully implemented particularly at times when the economy is benefiting from high oil prices. The current ninth development plan which covers the period from 2010-2014 aims to improve the infrastructure of the economy, strengthen the private sector and promote regional development (Ramady, 2010). Whether the economy will be diversified to particularly non-oil sectors will be essential for the sustainability of the economic growth in Saudi Arabia as well.

Iran is the second largest oil producer in OPEC coming after Saudi Arabia. Oil consumption in Iran is also quite high due to growing population and the related energy requirement. Based on Central Bank of Iran data, crude oil exports constitute around $90 \%$ of total exports and $60 \%$ of government revenues which suggests that Iran is highly vulnerable to oil shocks. Farzanegan and Markwardt (2009) state that Iran has high budget deficits (due to the large scale of state subsidies on energy and comestible goods) and needs to spend most of the oil revenues on financing high budget deficits, differently from the other oil-exporting countries. Other than the vulnerabilities from the budget side via negative oil price shocks', positive oil price shocks also create weakness on competitiveness in tradable goods due to appreciation in exchange rates. This may result in economic contraction in the long run ${ }^{13}$ and especially when oil reserves are about to be depleted, which is not only specific to Iran. US Energy Information Agency's (EIA) October 2012 report claims that there will be a decline in Iran's crude oil production capacity “due to the country's inability to carry out investment projects that are necessary to offset the natural decline in production from existing wells." Moreover,

\footnotetext{
${ }^{13}$ This is referred as Dutch disease.
} 
the Iranian economy faces an additional challenge, from political disputes with EU economies and the US. Recently, EU countries have banned importing crude oil from Iran over its nuclear program. However, exposure of Iranian economy to oil price shocks does not seem to prolong due to prospective nuclear technology.

The UAE is the third biggest economy in Middle East and North African (MENA) region (after Saudi Arabia and Iran) and holds the seventh-largest proved reserves of both crude oil and natural gas. Even if oil industry accounts for the major part in economic activity, UAE have made a remarkable progress in diversifying its economy through tourism, trade, and manufacturing. IMF 2012 report for the United Arab Emirates clarifies that UAE has developed into a major services hub in the Middle East which led to a significant decline in dependency on oil exports. High oil prices and strong growth in Asia are also suggested to be the contributors to the UAE economy. A pronounced negative oil prices shock due to a slow down in the growth prospects of the advanced economies and emerging Asian economies will affect export earnings, fiscal revenues and ultimately non-hydrocarbon GDP growth, with an adverse impact on asset prices. Projections suggest worse economic scenarios under prolonged drop in oil prices. Other than oil price vulnerability, the UAE reflect weakness in the construction and real estate sectors. However, strong trade, tourism, logistics, and manufacturing sectors are now driving growth and expect to relieve the vulnerability on oil price shocks (IMF, United Arab Emirates - 2012 Article IV Consultation).

Hence, this study has aimed to show that there is a transmission from the high growth rates of the engines of the world economy, namely from China and India to Middle East Economies. The critical point of this transmission is the high oil prices mainly caused by the demand of the China and India to oil exporting (MEEs). This study called it as oil-growth multiplier. The multiplier is likely to extend to other Middle East Economies including non-oil exporting countries like Turkey due to import and investment demand of (MEEs). That seems to be an interesting question for further studies.

Similarly, another interesting question would be on the role of oil exporting countries for the capital outflows and its impact on the restructuring of western financial system. Global current account imbalances have risen very sharply in the last few years with the deteriorating current account balance in the US and improving balance in South and East Asian economies. 
Figure 7: Current account balance (BoP, current billion US\$)

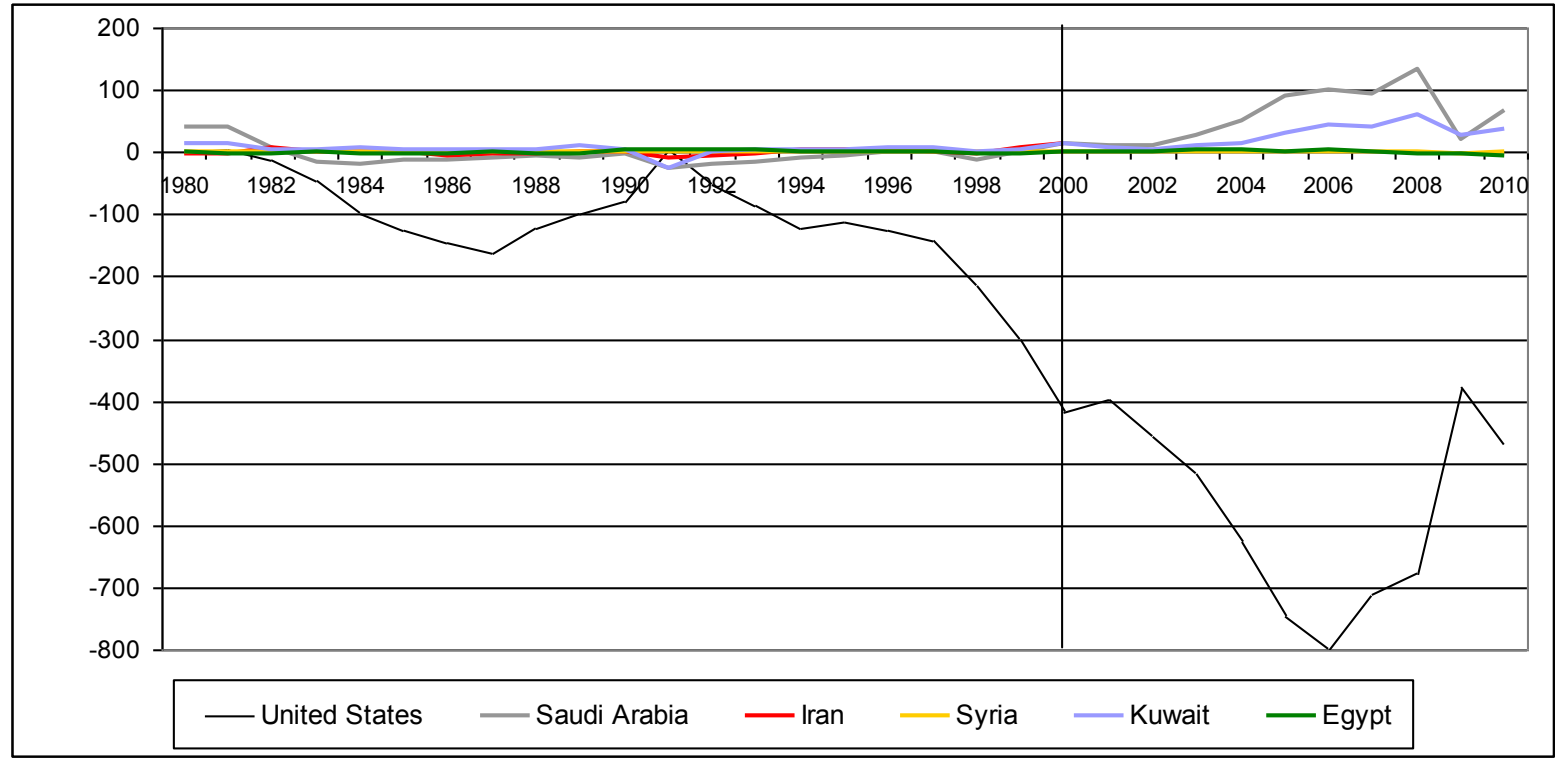

Source: World Bank (www.data.worldbank.org)

Worsening net external positions in the U.S. brings about the need for financing this deficit. Advanced Asian economies ${ }^{14}$ have become the main financial creditor for the U.S. Recently; oil exporting countries became a part of this process together with the rise in their current account balance and international reserves since the dollar is used within the oil trade. Figure 7 shows the current account balance of the US and MEEs. Chinn and Ito (2007) remark that oil exporting countries now highly involve in the world capital flow movements since they have high current account surpluses and these surpluses should be offset somewhere which is the US, according to the authors. However, WEO (2012) projections suggest that global imbalances are no longer expected to expand, due to the contribution of lower surpluses from Japan and the oil exporters and of lower deficits from the US and other economies. Those questions also remain for further studies.

\footnotetext{
${ }^{14}$ Advanced Asian economies refer to countries such as China, Japan, South Korea.
} 


\section{References}

Chinn, M.D. and Ito, H. 2009, "Global Current Account Imbalances: American Fiscal Policy versus East Asian Savings", La Follette School Working Paper No. 2007-012.

<http://www.lafollette.wisc.edu/publications/workingpapers >, Accessed August 21, 2012.

Dasgupta, D., Keller, J. and Srinivasan, T.G., 2002. "Reform and Elusive Growth in the Middle-East: What Has Happened in the 1990s?", World Bank Working Paper Series, No. 25.

Esfahani, H. S., Mohaddes, K., Pesaran, M. H., 2010. "Oil Exports and the Iranian Economy", Quarterly Review of Economics and Finance, in press.

Farzanegan, Mohammad Reza and Markwardt,Gunther, 2009. "The effects of oil price shocks on the Iranian economy", Energy Economics, Vol. 31, pp. 134-151.

Ghosh, S., 2009. "Import demand of crude oil and economic growth: Evidence from India", Energy Policy, Vol. 37, pp. 699-702.

Hamilton, J. D., 2008. "Understanding Crude Oil Prices", NBER Working Paper Series, No. 14492.

Hamilton, J. D., 2012. "Oil Prices, Exhaustible Resources, and Economic Growth. NBER Working Paper Series, No. w17759.

International Monetary Fund, World Economic Outlook, Growth Resuming, Dangers Remain, 2012, April.

International Monetary Fund, Kuwait-2012 Article IV Consultation Concluding Statement of the IMF Mission www.imf.org

International Monetary Fund, United Arab Emirates — Staff Report for the 2012 Article IV Consultation, April 27, 2012.

<http://www.imf.org/external/pubs/ft/scr/2012/cr12116.pdf $>$, Accessed October 21, 2012.

Kilian, L., 2008. "The Economic Effects of Energy Price Shocks", Journal of Economic Literature, Vol. 46, No. 4, pp. 871-909.

Leung, G.C.K., 2010, "China’s oil use, 1990-2008", Energy Policy, Vol. 38, pp. 932-944.

$\mathrm{Mu}, \mathrm{X}$. and Ye, H., 2011. "Understanding the Crude Oil Price: How Important Is the China Factor?", The Energy Journal, Vol. 32, No. 4. pp. 69-91.

Pesaran, M. H., Shin, Y. and Smith, R. J., 2001. "Bounds testing approaches to the analysis of level relationships", Journal of Applied Econometrics, Vol. 16, pp 289-326.

Ramady, M. A. 2010. The Saudi Arabian Economy, Second Edition, Springer, NY -2010.

Smith, J. L., 2009. "World Oil: Market or Mayhem?", The Journal of Economic Perspectives, Vol. 23, No. 3, pp. 145-164. 
Topics in Middle Eastern and African Economies

Vol. 15, No. 2, September 2013

US Energy Information Agency, October 2012 Report.

<http://www.eia.gov/forecasts/steo/pdf/steo_full.pdf>, Accessed October 21, 2012.

World Oils 2013. Oil Price History, Research, and Analysis System

<http://www.worldoils.com/oilprice.php> 